\title{
RESPONSE OF PEA (Pisum sativum L.) PLANT GROWN IN SAND CULTURE UNDER SALINITY STRESS TO FOLIAR APPLICATION BY KINETIN AND GIBBERELLIC ACID. Elsokkary, I. H. ; A. Y. Mourad ; A. Abdelhady and E. A. Abdallah Soil and Water Sci. Dept., Fac. Agric., Alex. Univ., Egypt.
}

\begin{abstract}
Pot experiment was carried out at Faculty of Agriculture, El Bostan, Alexandria University in order to estimate the response of pea plant (Pisum sativum L., variety Master B) grown in sand culture under salinity stress to foliar application by kinetin or gibberillic Acid $\left(\mathrm{GA}_{3}\right)$.

Seeds of pea were sown in plastic pot of $20 \mathrm{~cm}$ diameter and $30 \mathrm{~cm}$ depth containing $10 \mathrm{~kg}$ prewashed sand. The water of irrigation consisted from base nutrient solution of Hoagland containing $0,25,50$ and $100 \mathrm{mM} \mathrm{NaCl}$. After three weeks from sowing, the plants were foliar sprayed by 0,25 and $50 \mathrm{mg}$. kinetin $\mathrm{I}^{-1}$ or by 0,50 and $100 \mathrm{mg} .\left.\mathrm{GA}_{3}\right|^{-1}$. Samples of plants were collected after 38 and 88 days from sowing.

The obtained results showed significant decrease of the growth characters of 38 days old plant with increasing salinity. At $100 \mathrm{mM} \mathrm{NaCl}$ treatment, the relative decrease of shoot F.W. was $59.0 \%$ and that of root was $71.7 \%$. There were also significant decreases of $\mathrm{Chl} \mathrm{b}$, and carotenoids and significant increase of proline contents with increasing salinity.

There were no significant stimulating effects due to foliar application by kinetin on all growth characters, $\mathrm{Chl}$ a, Chl b and proline contents. However, foliar application by $\mathrm{GA}_{3}$ improved growth characters, at each salinity level, of 38 days old plants. However, there were significant reductions in grains F.W. of 88 days old plant with foliar application of $\mathrm{GA}_{3}$ at each level of salinity treatment.

Keywords : Pea plant, Relative growth rate (RGR), Kinetin, Gibberellic acid $\left(\mathrm{GA}_{3}\right)$, Salinity stress.
\end{abstract}

\section{INTRODUCTION}

Salinity is an a abiotic stress adversely affecting plant growth. High salinity can limit plant productivity and leads to dwarfism and inhibit root growth. It can reduce the ability of plant root to take up water and this quickly cause reduction in plant growth rate. In salt-sensitive plants, shoot and to less extent root growth is permanently reduced within hours of salt stress and this effect does not appear to depend on $\mathrm{Na}^{+}$concentrations in the growing tissues, but rather is a response to the osmolarity of the external solution (Munns, 2002, and Tester and Davenport, 2003),.

Osmotic adjustment in plant subjected to salt stress can occur by accumulation of high concentrations of either inorganic ions or low molecular organic solutes. The compatible osmolytes generally found in higher plants are low molecular weight sugars, organic acids, amides, amino acids and soluble proteins (Ashraf and Harris,2004).

Pea (Pisum sativum L.), a winter season food legume is grown in Egypt and other countries of the Meditteream region and, therefore, is adversely affected by salinity. Fedina and Tsonev (1997) found that salt stress leeds to reduction in the growth of shoot and root of pea plant exposed to salinization 
with $30 \mathrm{mM} \mathrm{NaCl}$ for 3 and 6 days. They also found that the chlorophyll a chlorophyll $b$ and carotenoids contents were declined but free praline content was increased at $30 \mathrm{mM} \mathrm{NaCl}$ treatment. Several studies reported that salt. Stressed pea plant contains high concentrations of proline (Olmos and Hellin, 1996; Lutts et al. 1999; Tester and Davenport, 2003). and Kumar et al., 2003. It has been also reported that praline accumulation in plants leaves has been the consequence of salinity (Ahmadi et al., 2009).

Recently, plant growth regulators have been applied in order to overcome the deleterious effects of salt stress. Kinetin is one of the cytokinins hnown to improve the growth of plants grown under salinity (Gadallah, 1999). Also, foliar application of gibberellic acid $\left(\mathrm{GA}_{3}\right)$ overcomes the effect of salt stress and improve growth parameters, yield and yield components of saltstressed plant (Akbari et al., 2008).

The objectives of this study, therefore, were to assess the effect of salinity on the growth characters of pea plant and to estimate the response of this plant to foliar application by kinetin or gibberellic acid.

\section{MATERIALS AND METHODS}

\section{Experimental Layout :}

Pot experiment was carried out at the greenhouse, Faculty of Agriculture at El-Bostan, Alexandria University to investigate the effects of foliar application of kinetin or gibberellic acid on the growth characters of pea (Pisum sativum L., variety Master B) plant grown in sand culture under salt stress.

Modified Hoaghand and Arnon nutrient solution was used as the base solution (Hewitt,1966). The concentrations of macro-and secondary- nutrients in this base solution are : 112.62, 14.52, $31.00197 .23,72.35,23.90$ and $32.01 \mathrm{mg}^{-1}$ for $\mathrm{N}-\mathrm{NO}_{3}, \mathrm{~N}-\mathrm{NH}_{4}, \mathrm{P}, \mathrm{K}, \mathrm{Ca}, \mathrm{Mg}$ and $\mathrm{S}$, respectively, and those of micronutrients are : $0.25,0.25,0.01,0.025,0.30$ and $0.025 \mathrm{mgl}-1$ for $\mathrm{B}, \mathrm{Mn}$, $\mathrm{Cu}, \mathrm{Zn}, \mathrm{Fe}$ and Mo, respectively. The used water of irrigation consisted of both the base nutrient solution containing 0.25 .50 and $100 \mathrm{mM} \mathrm{NaCl}$.

Split plot layout, in randomized completely block design, with six replicates was used; three replicates were collected after 38 days from sowing and the other three were collected after 88 days. The main plot treatments were four salt levels $(0,25,50$ and $100 \mathrm{mM} \mathrm{NaCl})$ and the subplot treatments were three kinetin levels $\left(0,25,50\right.$ and $\left.50 \mathrm{mg}^{-1} \mathrm{I}^{-1}\right)$ or three

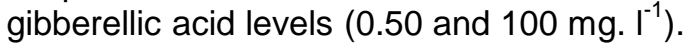

Seeds of pea were surface sterilized by soaking in $\mathrm{H}_{2} \mathrm{O}_{2}(10 \%)$ for 10 min, then washed thoroughly by tap water then by distilled water (Hewitt,1961). Ten seeds were sown in plastic pot of $20 \mathrm{~cm}$ diameter and 30 $\mathrm{cm}$ depth containing $10 \mathrm{~kg}$ pre-washed sand (Hewitt, 1961). Each pot was irrigated daily by tap water and after 11 days the plants were thinned to four seedlings per pot. Each pot was then irrigated daily by one liter irrigation solution. After three weeks from sowing, the plants were foliar sprayed two times, a week interval, by $100 \mathrm{ml}$ per pot solution of kinetin or gebberellic acid 
and the control treatment was foliar sprayed with $100 \mathrm{ml}$ distilled water per pot.

Plant Sampling :

Samples of plant were collected after 38 and 88 days from planting, washed with tap water then by distilled water. The fresh weight (F.W) of plant organs of the first collection (shoot and root) and those of the second collection (shoot, root, pods and grains) were measured. Proportion of the fresh leaves were preserved for photosynthetic pigments and proline analysis. The plant organs were then oven-dried at $65^{\circ} \mathrm{C}$ for $48 \mathrm{hrs}$, and the oven-dried weights were measured, then finely ground using stainless steal mill and kept for analysis.

Plant Analysis :

Photosynthetic pigments : Half gram fresh leaves was cut to small pieces, extracted with $110 \mathrm{ml} \mathrm{N,N-Dimethylformamide.} \mathrm{The} \mathrm{optical} \mathrm{density} \mathrm{was}$ measured at wave length of $662 \mathrm{~nm}$ for chlorophyll a (Chl a), of $644 \mathrm{~nm}$ for chlorophyll b (Chl b), and of $440 \mathrm{~nm}$ for carotenoids using spectrophotometer (Jenway 6305 UV/Vis spectrophotometer). The following equations were used : $\mathrm{Chl} \mathrm{a}=9.784 \mathrm{E} 662-0.99 \mathrm{E} 644=\mathrm{mg} \mathrm{l}^{-1}, \mathrm{Chl} \mathrm{b}=21.426 \mathrm{E} 644-4.65$ $\mathrm{E} 662=\mathrm{mg} \mathrm{l}^{-1}$, carotenoids $=4.695 \mathrm{E} 440-0.268(\mathrm{Chl} \mathrm{a}+\mathrm{Chl} \mathrm{b})=\mathrm{mg} \mathrm{I}^{-1}$, where $\mathrm{E}$ is the optical density at the wave length indicated (Moran and Porath, 1980).

Proline : The concentration of praline was measured in fully expanded fresh leaves according to the method described by Bates et al. (1973).

Total sugars : The concentration of total sugars was determined in the grinding oven- dried grains according to the method described by Dubois et al (1956).

\section{Statistical Analysis}

The data obtained were statistically analyzed for the least significant difference using the SAS statistical analysis software (SAS Inst. 1985).

\section{RESULTS AND DISCUSSION}

Under the growth conditions of this study, pea plants grew smaller and flowering was more prolific under salinity conditions (data not shown). The following paragraphs outline the data obtained under salinity treatments and growth regulators foliar application.

\section{Effect of Salinity- Kinetin Interaction}

Pea plant after 38 days from sowing

Growth characters : Table 1 showed significant decrease of shoot F.W. at $100 \mathrm{mM} \mathrm{NaCl}$ irrigation treatment and that of root F.W. at $50 \mathrm{mM} \mathrm{NaCl}$ irrigation treatment. This indicates that pea plant root is more sensitive to salinity than shoot. However, on the D.W. basis, significant decrease was found for shoot and root at $50 \mathrm{mM} \mathrm{NaCl}$.

The values of the relative decrease of shoot F.W. were 2.4, 21.5 and $59.0 \%$, and those of root F.M. were 3.3, 36.3 and $71.7 \%$ at 25,50 and 100 $\mathrm{mM} \mathrm{NaCl}$ treatments, respectively. On the D.W. basis, these values were 
11.6, 39.1 and $62.1 \%$ for shoot, and were $18.0,44.0$ and $66.0 \%$ for root, at 25,50 and $100 \mathrm{mM} \mathrm{NaCl}$ treatments, respectively. Thus, the relative reduction in shoot growth was less than of the root. This means that pea plant root is more sensitive to salinity than shoot.

Table 1:The mean value of growth characters of pea plant after 38 days from sowing as influenced by $\mathrm{NaCl}$ and kinetin concentrations interactions.

\begin{tabular}{|c|c|c|c|c|c|c|c|c|}
\hline \multicolumn{2}{|c|}{ Treatments } & \multicolumn{2}{|c|}{ Shoot (g.plant ${ }^{-1}$ ) } & \multicolumn{2}{|c|}{ Root (g.plant ${ }^{-1}$ ) } & \multicolumn{2}{|c|}{ Sh/Rt ratio } & \multirow{2}{*}{$\begin{array}{c}\text { Shoot } \\
\text { height }(\mathrm{cm})\end{array}$} \\
\hline $\begin{array}{l}\mathrm{Nacl} \\
(\mathrm{mM})\end{array}$ & $\begin{array}{l}\text { Kinetin } \\
\left(\mathrm{mg} . \mathrm{I}^{-1}\right)\end{array}$ & F.W. & D.W. & F.W. & D.W. & F.W. & D.W. & \\
\hline 0 & $\begin{array}{l}0 \\
25 \\
50\end{array}$ & $\begin{array}{l}6.97 a \\
6.80 a \\
5.59 a\end{array}$ & $\begin{array}{c}0.69 a \\
0.66 a b \\
0.58 a b\end{array}$ & $\begin{array}{l}10.69 \mathrm{a} \\
10.69 \mathrm{a} \\
8.75 \mathrm{ab}\end{array}$ & $\begin{array}{c}0.50 \mathrm{a} \\
0.48 \mathrm{ab} \\
0.40 \mathrm{ac}\end{array}$ & $\begin{array}{l}0.65 \mathrm{de} \\
0.64 \mathrm{de} \\
0.66 \mathrm{de}\end{array}$ & $\begin{array}{l}1.39 \mathrm{a} \\
1.37 \mathrm{a} \\
1.48 \mathrm{a}\end{array}$ & $\begin{array}{c}20.7 \mathrm{ab} \\
21.0 \mathrm{a} \\
20.3 \mathrm{ab}\end{array}$ \\
\hline 25 & $\begin{array}{l}0 \\
25 \\
50\end{array}$ & $\begin{array}{l}6.80 a \\
5.90 a \\
6.49 a\end{array}$ & $\begin{array}{l}0.61 \mathrm{ac} \\
0.50 \mathrm{bd} \\
0.59 \mathrm{ad}\end{array}$ & $\begin{array}{c}10.43 \mathrm{ab} \\
9.48 \mathrm{ab} \\
9.59 \mathrm{ac}\end{array}$ & $\begin{array}{l}0.41 \mathrm{ac} \\
0.39 \mathrm{bc} \\
0.43 \mathrm{ac}\end{array}$ & $\begin{array}{c}0.65 \mathrm{de} \\
0.62 \mathrm{e} \\
0.68 \mathrm{de}\end{array}$ & $\begin{array}{l}1.48 \mathrm{a} \\
1.28 \mathrm{a} \\
1.36 \mathrm{a}\end{array}$ & $\begin{array}{l}19.9 \text { ac } \\
19.4 \text { ac } \\
19.9 \text { ac }\end{array}$ \\
\hline 50 & $\begin{array}{l}0 \\
25 \\
50\end{array}$ & $\begin{array}{l}5.47 a \\
5.61 a \\
5.27 a\end{array}$ & $\begin{array}{c}0.42 \mathrm{~d} \\
0.49 \mathrm{bd} \\
0.44 \mathrm{~cd}\end{array}$ & $\begin{array}{c}6.81 \mathrm{~cd} \\
7.54 \mathrm{bd} \\
6.28 \mathrm{~d}\end{array}$ & $\begin{array}{c}0.28 \mathrm{~d} \\
0.33 \mathrm{~cd} \\
0.29 \mathrm{~d}\end{array}$ & $\begin{array}{l}0.81 \text { be } \\
0.76 \text { ce } \\
0.84 \text { bd }\end{array}$ & $\begin{array}{l}1.52 \mathrm{a} \\
1.53 \mathrm{a} \\
1.55 \mathrm{a}\end{array}$ & $\begin{array}{l}17.7 \mathrm{bc} \\
20.5 \mathrm{ab} \\
17.0 \mathrm{~cd}\end{array}$ \\
\hline 100 & $\begin{array}{l}0 \\
25 \\
50\end{array}$ & $\begin{array}{l}2.86 \mathrm{~b} \\
2.48 \mathrm{~b} \\
2.83 \mathrm{~b}\end{array}$ & $\begin{array}{l}0.24 \mathrm{e} \\
0.22 \mathrm{e} \\
0.26 \mathrm{e}\end{array}$ & $\begin{array}{l}3.03 \mathrm{e} \\
2.62 \mathrm{e} \\
2.72 \mathrm{e}\end{array}$ & $\begin{array}{l}0.17 \mathrm{e} \\
0.13 \mathrm{e} \\
0.16 \mathrm{e}\end{array}$ & $\begin{array}{c}0.93 \mathrm{ac} \\
0.99 \mathrm{ab} \\
1.04 \mathrm{a}\end{array}$ & $\begin{array}{l}1.54 \mathrm{a} \\
1.76 \mathrm{a} \\
1.74 \mathrm{a}\end{array}$ & $\begin{array}{c}13.4 \mathrm{e} \\
13.9 \mathrm{e} \\
14.7 \mathrm{de}\end{array}$ \\
\hline $\mathrm{LSD}_{0.05}$ & & 1.65 & 0.16 & 2.78 & 0.10 & 0.18 & 0.51 & 2.8 \\
\hline
\end{tabular}

The data obtained showed that the amounts of moisture content in shoot decreased from $6.28 \mathrm{~g}$. plant $^{-1}$, at $00 \mathrm{mM} \mathrm{NaCl}$ (the control plant) to

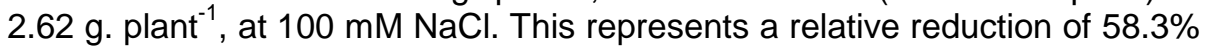
in the moisture control of shoot of plant grown under $100 \mathrm{mM} \mathrm{NaCl}$. These amounts decreased in roots from 10.19 g. plant $^{-1}$ (the control plant) to 2.86 g. plant $^{-1}$ (at $100 \mathrm{mM} \mathrm{NaCl}$ ). This represents a relative reduction of $71.9 \%$ in the moisture content of root of plant grown under $100 \mathrm{mM} \mathrm{NaCl}$. These data point out to high reduction in the amount of water taken up by plant when grown under high salinity. Since the moisture control at $100 \mathrm{mM} \mathrm{NaCl}$ in shoot (2.62 g.plant $\left.{ }^{-1}\right)$ and root (2.80 g.plant $\left.{ }^{-1}\right)$ are very close this points out that high salinity reduces the ability of plant root to take up water from the saline medium and the rate of water tansport from root to shoot is very low. Munns and Passioura (1984) found that the dehydration of shoot and root with increasing $\mathrm{NaCl}$ concentration was associated with significant decrease in both the fresh and dry weights of plant. It has been also reported that the mechanisms controlling the growth response to high salt concentration are not specific to salinity. The reductions in the rate of leaf and root growth are probably due to factors associated with water stress rather than a salt sqecific effect (Munns, 2002).

Table 1 showed marked increase in the values of Sh/Rt ratio, on both F.W. and D.W. basis, with increasing $\mathrm{NaCl}$ concentration treatments. The highest Sh/Rt ratio was at $100 \mathrm{mM} \mathrm{NaCl}$. This is due to high reduction in the growth rate of root relative to that of shoot. Also, the observed higher values of Sh/Rt ratio on D.W. basis than on F.W. basis indicate higher moisture content in root than in shoot, at each $\mathrm{NaCl}$ treatment. 
Table 1 showed also significant decrease in plant height with increasing the concentration of $\mathrm{NaCl}$ in the water of irrigation, especially at 50 and $100 \mathrm{mM} \mathrm{NaCl}$. The relative reductions in plant height were 3.9, 14.5 and $35.5 \%$ at 25,50 and $100 \mathrm{mM} \mathrm{NaCl}$, respectively.

Photosynthetic pigments : Table 2 showed significant decrease in the concentration of $\mathrm{Chl}$ a at $50 \mathrm{mM} \mathrm{NaCl}$, while that of $\mathrm{Chl} b$ was not significant.

The concentration of carotenoids significantly decreased only at $50 \mathrm{mM}$ $\mathrm{NaCl}$ treatment. The relative reductions in the concentration of $\mathrm{Chl}$ a were 5.0, 15.5 and $17.8 \%$ and those of $\mathrm{Chl} b$ were $0.5,13.7$ and $12.4 \%$ at 25,50 and $100 \mathrm{mM} \mathrm{NaCl}$ treatments, respectively. This points out to high sensitivity of the photosynthetic system to high salinity. Wang et al. (2007) found that chlorophyll content in leaves of wheat seedlings was decreased by 27.5 and $51.6 \%$ under salinity of 150 and $300 \mathrm{mM} \mathrm{NaCl}$, respectively. They reported that the growth of wheat seedlings was decreased by salinity and the relative reductions of plant biomass were 36.1 and $46.5 \%$ at 150 and $300 \mathrm{mM} \mathrm{NaCl}$, respectively.

Table 2: The mean value of the concentrations of photosynthetic pigments (mg.100-1 F.W) in leaves of pea plant after38 days from sowing and of proline $\left(\mu M . g^{-1}\right.$ F.W) as influenced by $\mathrm{NaCl}$ and kinetin concentrations interactions.

\begin{tabular}{|c|c|c|c|c|c|}
\hline \begin{tabular}{|l|} 
Treatments \\
$\mathrm{NaCl}(\mathrm{mMM}$
\end{tabular} & Kinetin (mq. $\mathbf{l}^{-1}$ ) & Chl a & Chl b & Carotenoids & Proline \\
\hline 0 & $\begin{array}{l}0 \\
25 \\
50\end{array}$ & $\begin{array}{c}73.52 \mathrm{ab} \\
75.58 \mathrm{a} \\
75.20 \mathrm{a}\end{array}$ & $\begin{array}{c}37.98 \mathrm{ab} \\
40.36 \mathrm{a} \\
40.26 \mathrm{a}\end{array}$ & $\begin{array}{c}30.78 \mathrm{ab} \\
31.90 \mathrm{a} \\
31.72 \mathrm{a}\end{array}$ & $\begin{array}{l}1.26 \mathrm{~b} \\
0.85 \mathrm{~b} \\
0.96 \mathrm{~b}\end{array}$ \\
\hline 25 & $\begin{array}{l}0 \\
25 \\
50\end{array}$ & $\begin{array}{l}69.83 \text { ac } \\
64.28 \text { be } \\
68.36 \text { ad }\end{array}$ & $\begin{array}{l}37.78 \mathrm{ab} \\
33.71 \mathrm{bc} \\
36.52 \mathrm{ac}\end{array}$ & $\begin{array}{l}28.06 \text { ac } \\
27.45 \text { ac } \\
28.11 \text { ac }\end{array}$ & $\begin{array}{l}0.86 b \\
0.79 b \\
0.75 b\end{array}$ \\
\hline 50 & $\begin{array}{l}0 \\
25 \\
50\end{array}$ & $\begin{array}{c}62.15 \mathrm{cf} \\
52.58 \mathrm{f} \\
57.78 \mathrm{ef}\end{array}$ & $\begin{array}{c}32.77 \mathrm{bd} \\
27.26 \mathrm{~d} \\
30.65 \mathrm{~cd}\end{array}$ & $\begin{array}{c}25.77 \text { bc } \\
23.99 \mathrm{c} \\
25.69 \mathrm{bc}\end{array}$ & $\begin{array}{l}0.75 b \\
0.82 b \\
0.97 b\end{array}$ \\
\hline 100 & $\begin{array}{l}0 \\
25 \\
50\end{array}$ & $\begin{array}{l}60.47 \mathrm{cf} \\
59.22 \mathrm{df} \\
66.21 \mathrm{ac}\end{array}$ & $\begin{array}{l}33.29 \mathrm{bd} \\
32.77 \mathrm{bd} \\
36.15 \mathrm{ac}\end{array}$ & $\begin{array}{c}28.71 \mathrm{ac} \\
28.31 \mathrm{ac} \\
31.10 \mathrm{a}\end{array}$ & $\begin{array}{l}5.37 \mathrm{a} \\
4.72 \mathrm{a} \\
5.57 \mathrm{a}\end{array}$ \\
\hline $\operatorname{LSD}_{0.05}$ & & 8.94 & 5.68 & 4.83 & 2.24 \\
\hline
\end{tabular}

Proline : Table 2 showed significant increase in the concentration of praline in leaves of pea plant only at $100 \mathrm{mM} \mathrm{NaCl}$ concentration treatment. However, there were marked reductions in proline contents at 25 and $50 \mathrm{mM}$ $\mathrm{NaCl}$ treatments with relative decrease of 31.7 and $40.5 \%$, respectively. However, the relative increase in proline content at $100 \mathrm{mM} \mathrm{NaCl}$ was $325.2 \%$. Wang et al. (2007) found that the increase of proline in leaves of wheat seedlings was not remarkable at $150 \mathrm{mM} \mathrm{NaCl}$, but was significant at $300 \mathrm{mM} \mathrm{NaCl}$ with value of relative increase of $183.0 \%$. Several studies showed that Salt. stressed pea plants contained high concentration of proline in plant leaves (Olmos and Hellin, 1996; Fedina and Tsonev, 1997; Lutt. et al., 1999 and Tester and Davenport, 2003). It has been also reported that proline accumulation in plants leaves is the consequence of salinity (Ahmadi 
et al., 2009). It has been proposed that praline accumulation can serve as an adaptive mechanism to salt stress in higher plants (Kumar et al., 2003).

Salinity kinetin interaction : Table1 showed no significant effect of foliar application of kinetin on the growth characters of pea plant at each level of salinity treatment. However, Gadallah (1999) found that foliar application of kinetin had ameliorated the deleterious effect of salinity on the growth of shoot of wheat plant. It is also clear that foliar application of kinetin has no significant effects on the concentrations of $\mathrm{Chl} \mathrm{a}$, Chl b, carotenoids and proline in leaves of pea plant treated with different concentration of $\mathrm{NaCl}$.

\section{Pea plant after 88 days from sowing}

Growth characters : Table 3 showed significant decrease in the fresh weight of shoot, root, pods and grains with $\mathrm{NaCl}$ concentration of $50 \mathrm{mM}$. It is also clear that the growth of pea plant totally inhibited with irrigation water containing $100 \mathrm{mM} \mathrm{NaCl}$. The relative reductions in shoot F.W. were 04, 41.8 and $100 \%$, and those of root F.W. were 15.8, 41.4 and $100 \%$ at 25,50 and $100 \mathrm{mM} \mathrm{NaCl}$ treatments, respectively. These values for pods F.W. were 3.7, 46.0 and 100\%, and those for grains F.W. were 33.2, 62.8 and $100 \%$, respectively. The total inhibition of plant growth under $100 \mathrm{mM} \mathrm{NaCl}$ treatment could be due to the excessive accumulation of salt in plant which can eventually rise to toxic levels that plant cannot sustain growth. Similar trend was found with respect to grains D.W. in relation to salinity since the relative reduction of grains D.W. was $69.9 \%$ at $50 \mathrm{mM} \mathrm{NaCl}$. It can be concluded that salt inhibits plant growth for two reasons; first : the presence of salt reduces the ability of the plant to take up water and leads to slower growth; second: excessive amount of salt entering the transpiration stream will eventually injure cells in the transpiring leaves and this may further reduce plant growth (Munns et al., 2006).

Table 3 :The mean value of growth characters and total sugars of pea plant after 88 days from sowing as influenced by $\mathrm{NaCl}$ and kinetin concentrations interactions.

\begin{tabular}{|c|c|c|c|c|c|c|c|}
\hline \multicolumn{2}{|c|}{ Treatments } & \multicolumn{4}{|c|}{ Fresh weight (g.plant $^{-1}$ ) } & \multirow{2}{*}{$\begin{array}{c}\text { Grains D.W } \\
\text { (g.plant }^{-1} \text { ) }\end{array}$} & \multirow{2}{*}{$\begin{array}{c}\text { Total } \\
\text { sugars } \\
\text { (mg.g } \\
\text { D.W.) }\end{array}$} \\
\hline $\begin{array}{l}\text { Nacl } \\
(\mathrm{mM})\end{array}$ & $\begin{array}{l}\text { Kinetin } \\
\text { mg. } .^{-1}\end{array}$ & shoot & Root & Pods & Grains & & \\
\hline 0 & $\begin{array}{l}0 \\
25 \\
50\end{array}$ & $\begin{array}{l}46.37 \mathrm{a} \\
42.08 \mathrm{a} \\
40.95 \mathrm{a}\end{array}$ & $\begin{array}{c}31.58 \mathrm{ac} \\
35.17 \mathrm{a} \\
32.53 \mathrm{ab}\end{array}$ & $\begin{array}{c}43.07 \mathrm{a} \\
34.43 \mathrm{ab} \\
28.87 \mathrm{ab}\end{array}$ & $\begin{array}{l}19.36 \mathrm{a} \\
11.84 \mathrm{~b} \\
10.13 \mathrm{~b}\end{array}$ & $\begin{array}{l}4.10 \mathrm{a} \\
2.38 \mathrm{~b} \\
2.15 \mathrm{~b}\end{array}$ & $\begin{array}{c}92.92 \mathrm{ac} \\
107.50 \mathrm{ac} \\
79.21 \mathrm{bc}\end{array}$ \\
\hline 25 & $\begin{array}{l}0 \\
25 \\
50\end{array}$ & $\begin{array}{c}46.20 \mathrm{a} \\
38.08 \mathrm{ab} \\
40.06 \mathrm{a}\end{array}$ & $\begin{array}{l}26.58 \mathrm{ad} \\
22.39 \mathrm{bd} \\
25.88 \mathrm{ad}\end{array}$ & $\begin{array}{c}41.49 \mathrm{a} \\
34.41 \mathrm{ab} \\
29.58 \mathrm{ab}\end{array}$ & $\begin{array}{c}12.94 \mathrm{ab} \\
12.95 \mathrm{ab} \\
11.04 \mathrm{~b}\end{array}$ & $\begin{array}{l}2.54 \mathrm{~b} \\
2.54 \mathrm{~b} \\
2.11 \mathrm{~d}\end{array}$ & $\begin{array}{l}107.67 \mathrm{ac} \\
137.25 \mathrm{bc} \\
104.71 \mathrm{ac}\end{array}$ \\
\hline 50 & $\begin{array}{l}0 \\
25 \\
50\end{array}$ & $\begin{array}{c}26.98 \mathrm{bc} \\
22.17 \mathrm{c} \\
27.91 \mathrm{bc}\end{array}$ & $\begin{array}{c}18.51 \mathrm{~d} \\
16.62 \mathrm{~d} \\
21.53 \mathrm{~cd}\end{array}$ & $\begin{array}{c}23.26 \mathrm{a} \\
22.13 \mathrm{~b} \\
29.74 \mathrm{ab}\end{array}$ & $\begin{array}{c}7.21 \mathrm{bc} \\
7.92 \mathrm{~b} \\
11.80\end{array}$ & $\begin{array}{c}1.48 \mathrm{be} \\
1.65 \mathrm{~b} \\
2.63 \mathrm{~b}\end{array}$ & $\begin{array}{c}141.84 \mathrm{a} \\
55.00 \\
16.69 \mathrm{~d}\end{array}$ \\
\hline 100 & $\begin{array}{l}0 \\
25 \\
50\end{array}$ & $\begin{array}{c}- \\
2.41 \mathrm{~d} \\
1.70 \mathrm{~d}\end{array}$ & $\begin{array}{c}- \\
0.95 \mathrm{e} \\
0.86 \mathrm{e}\end{array}$ & $\begin{array}{c}- \\
2.25 \mathrm{c} \\
2.17 \mathrm{c}\end{array}$ & $\begin{array}{c}- \\
0.54 \mathrm{c} \\
0.52 \mathrm{c}\end{array}$ & $\begin{array}{c}- \\
0.11 c \\
0.13 c\end{array}$ & $\begin{array}{c}-\overline{4} \\
14.45 \mathrm{~d} \\
14.64 \mathrm{~d}\end{array}$ \\
\hline $\mathrm{LSD}_{0.0}$ & & 11.47 & 10.21 & 14.17 & 6.87 & 1.38 & 60.32 \\
\hline
\end{tabular}

Relative growth rate (RGR): The RGR of pea plant, generally, decreased with increasing salinity. The relative growth rates of fresh shoot were 0.79 , 
0.79 and $0.43 \mathrm{~g} \cdot \mathrm{g}^{-1}$ day and those of fresh root were $0.42,0.33$ and $0.23 \mathrm{~g} \cdot \mathrm{g}^{-1}$ day at 0.25 and $50 \mathrm{mM} \mathrm{NaCl}$ treatments, respectively. The lower RGR of root than shoot points to higher sensitivity of pea root to salinity than shoot.

Total sugars : Table 3 showed marked and not significant increase in the concentration of total sugar in grains with increasing salinity. These levels were $92.92,107.67$ and $141.84 \mathrm{mg} \mathrm{g}^{-1}$ D.W. at 0,25 and $50 \mathrm{mM} \mathrm{NaCl}$ treatments, respectively. The accumulation of soluble carbohydrates in plant has been widely reported as a response to salinity (Ashraf and Harris, 2004).

Salinity- kinetin interaction: Foliar application of kinetin showed no significant effect on the growth characters of pea plant and also on total sugar content in grains (Table 1). This is evident by studying the values of RGR of fresh shoot at $00 \mathrm{mM} \mathrm{NaCl}$ with 0,25 and $50 \mathrm{mg}$. kinetin $\mathrm{I}^{-1}$ which were 0.79 , 0.71 and $0.71 \mathrm{~g} . \mathrm{g}^{-1}$ day. These values at $25 \mathrm{mM} \mathrm{NaCl}$ were $0.79,0.64$ and $0.61 \mathrm{~g}^{-1}$ day and at $50 \mathrm{mM} \mathrm{NaCl}$ were $0.43,0.33$ and $0.45 \mathrm{~g}^{-1}{ }^{-1}$ day, respectively. This reveals that foliar application of kinetin did not stimulate the growth of plant shoot at any salinity level. In the case of fresh root, values of RGR at $00 \mathrm{mM} \mathrm{NaCl}$ with $0,25,50 \mathrm{mg}$ kinetin I $^{-1}$ were $0.42,0.49$ and 0.48 $\mathrm{g} . \mathrm{g}^{-1}$ day, at $25 \mathrm{mM} \mathrm{NaCl}$ were $0.32,0.26$ and $0.32 \mathrm{~g} \cdot \mathrm{g}^{-1}$ day and at $50 \mathrm{mM}$ $\mathrm{NaCl}$ were $0.23,0.18$ and $0.31 \mathrm{~g} . \mathrm{g}^{-1}$ day, respectively. These data indicate that foliar application of kinetin did not stimulate the growth of root at any salinity level. However, as the plant growth totally inhibited at $100 \mathrm{mM} \mathrm{NaCl}$ treatment, foliar application of kinetin at level of $25 \mathrm{mg} \mathrm{I}^{-1}$ enhanced plant growth slightly. Relative to the control plant $\left(00 \mathrm{mMNaCl}\right.$ and $00 \mathrm{~g} \mathrm{I}^{-1}$ kinetin) and at $100 \mathrm{mM} \mathrm{NaCl}$ and foliar application of $25 \mathrm{mg}^{\text {kinetin I }} \mathrm{I}^{-1}$, the values of relative reductions were $94.3 \%$ for shoot F.W; $97.3 \%$ for root F.W; $93.4 \%$ for pods F.W. ; $95.4 \%$ for grain F.W.; $95.4 \%$ for grains D.W. and $86.6 \%$ for total sugars relative to $100 \mathrm{mM} \mathrm{NaCl}$ and $00 \mathrm{mg} \mathrm{kinetin}^{-1}$, treatment. Foliar application of $50 \mathrm{mg}$ kinetin I $^{-1}$ was relatively less effective in stimulating plant growth as $25 \mathrm{mg}$ kinetin I $^{-1}$ and, at $100 \mathrm{mM} \mathrm{NaCl}^{-1}$ treatment.

\section{Effect of Salinity- Gibberellic Acid Interaction}

\section{Pea plant at 38 days from sowing}

Growth characters : Table 4 showed significant decrease of shoot F.W. at $100 \mathrm{mM} \mathrm{NaCl}$ and that of shoot D.W. at $50 \mathrm{mM} \mathrm{NaCl}$. Also, there were significant decreases in root F.W. and D.W. at $50 \mathrm{mM} \mathrm{NaCl}$ treatment. The values of relative decrease of shoot F.W. were 2.4, 21.5 and $59.0 \%$ and those of root F.W. were 2.4, 36.3 and $71.7 \%$ at 25,50 and $100 \mathrm{mM} \mathrm{NaCl}$, respectively. These values on D.W. basis were $11.6,39.1$ and $65.2 \%$ for shoot, and $18.0,44.0$ and $66.0 \%$ for root at 25,50 and $100 \mathrm{mM} \mathrm{NaCl}$, respectively. This indicates higher reduction in the growth of root of pea plant than of shoot at each salinity level.

Table 4 also showed that the moisture contents in shoot were 6.28 , $6.19,5.05$ and $2.62 \mathrm{~g}$. plant ${ }^{-1}$ and those in root were $10.19,10.42,6.53$ and 2.86 g. plant ${ }^{-1}$ at $0,25,50$ and $100 \mathrm{mM} \mathrm{NaCl}$, respectively. Thus, there were marked decrease in moisture contents in plant organs with increasing salinity which were higher in root than in shoot at each $\mathrm{NaCl}$ treatment. This moisture reduction was associated with reduction in plant growth. 
Table 4 :The mean value of growth characters of pea plant after 38 days from sowing as influenced by the interaction between $\mathrm{NaCl}$ and gibberellic acid concentrations.

\begin{tabular}{|c|c|c|c|c|c|c|c|c|}
\hline \multicolumn{2}{|c|}{ Treatments } & \multicolumn{2}{|c|}{ Shoot (g plant ${ }^{-1}$ ) } & \multicolumn{2}{|c|}{ Root (g plant 1 ) } & \multicolumn{2}{|c|}{ Sh /Rt Ratio } & \multirow{2}{*}{$\begin{array}{c}\text { Shoot height } \\
(\mathrm{cm})\end{array}$} \\
\hline $\begin{array}{l}\mathrm{NaCl} \\
(\mathrm{mM})\end{array}$ & $\begin{array}{l}\text { Gib } \\
\left(\mathrm{mg} . \mathrm{I}^{-1}\right)\end{array}$ & F.W. & D.W. & F.W. & D.W. & F.W. & D.W. & \\
\hline 0 & $\begin{array}{l}0 \\
50 \\
100\end{array}$ & $\begin{array}{c}6.97 \mathrm{bc} \\
8.36 \mathrm{ac} \\
8.93 \mathrm{a}\end{array}$ & $\begin{array}{c}0.69 \mathrm{bc} \\
0.75 \mathrm{ac} \\
0.87 \mathrm{a}\end{array}$ & $\begin{array}{c}10.69 \mathrm{a} \\
9.53 \mathrm{a} \\
9.31 \mathrm{a}\end{array}$ & $\begin{array}{c}0.50 \mathrm{a} \\
0.46 \mathrm{ab} \\
0.40 \mathrm{~b}\end{array}$ & $\begin{array}{c}0.65 \mathrm{e} \\
0.88 \mathrm{~cd} \\
0.96 \mathrm{bd}\end{array}$ & $\begin{array}{c}1.39 \mathrm{~d} \\
1.68 \mathrm{~cd} \\
2.19 \mathrm{ac}\end{array}$ & $\begin{array}{c}20.74 \mathrm{de} \\
39.71 \mathrm{a} \\
41.75 \mathrm{a}\end{array}$ \\
\hline 25 & $\begin{array}{l}0 \\
50 \\
100\end{array}$ & $\begin{array}{c}6.80 \mathrm{cc} \\
8.72 \mathrm{ab} \\
9.47 \mathrm{a}\end{array}$ & $\begin{array}{l}0.61 \mathrm{~cd} \\
0.74 \mathrm{ac} \\
0.84 \mathrm{ab}\end{array}$ & $\begin{array}{c}10.43 \mathrm{a} \\
9.60 \mathrm{a} \\
9.39 \mathrm{a}\end{array}$ & $\begin{array}{c}0.41 \mathrm{ab} \\
0.40 \mathrm{~b} \\
0.37 \mathrm{~b}\end{array}$ & $\begin{array}{c}0.65 \mathrm{e} \\
0.92 \mathrm{~cd} \\
1.01 \mathrm{bc}\end{array}$ & $\begin{array}{c}1.48 \mathrm{~d} \\
1.85 \mathrm{bd} \\
2.26 \mathrm{ab}\end{array}$ & $\begin{array}{l}19.85 \mathrm{de} \\
38.71 \mathrm{ab} \\
39.08 \mathrm{ab}\end{array}$ \\
\hline 50 & \begin{tabular}{|l|}
0 \\
50 \\
100 \\
\end{tabular} & $\begin{array}{c}5.47 \mathrm{c} \\
8.20 \mathrm{ad} \\
6.46 \mathrm{dc}\end{array}$ & $\begin{array}{c}0.42 \mathrm{c} \\
0.69 \mathrm{bc} \\
0.49 \mathrm{dc}\end{array}$ & $\begin{array}{l}6.81 \mathrm{~b} \\
7.40 \mathrm{~b} \\
5.90 \mathrm{~b}\end{array}$ & $\begin{array}{c}0.28 \mathrm{c} \\
0.27 \mathrm{c} \\
0.21 \mathrm{~cd}\end{array}$ & $\begin{array}{l}0.81 \mathrm{~d} \\
1.11 \mathrm{~b} \\
1.10 \mathrm{~b}\end{array}$ & $\begin{array}{c}1.52 \mathrm{~d} \\
2.52 \mathrm{a} \\
2.36 \mathrm{ab}\end{array}$ & $\begin{array}{l}17.68 \mathrm{e} \\
35.08 \mathrm{~b} \\
31.04 \mathrm{c}\end{array}$ \\
\hline 100 & \begin{tabular}{|l|}
0 \\
50 \\
100 \\
\end{tabular} & $\begin{array}{l}2.86 \mathrm{f} \\
3.38 \mathrm{f} \\
3.42 \mathrm{f}\end{array}$ & $\begin{array}{l}0.24 \mathrm{f} \\
0.19 \mathrm{f} \\
0.17 \mathrm{f}\end{array}$ & $\begin{array}{l}3.03 \mathrm{c} \\
2.50 \mathrm{c} \\
2.59 \mathrm{c}\end{array}$ & $\begin{array}{l}0.17 \mathrm{~d} \\
0.08 \mathrm{e} \\
0.07 \mathrm{e}\end{array}$ & $\begin{array}{c}0.93 \mathrm{~cd} \\
1.36 \mathrm{a} \\
1.33 \mathrm{a}\end{array}$ & $\begin{array}{c}1.54 \mathrm{~d} \\
2.43 \mathrm{a} \\
2.39 \mathrm{ab}\end{array}$ & $\begin{array}{l}13.42 \mathrm{f} \\
22.33 \mathrm{~d} \\
22.47 \mathrm{~d}\end{array}$ \\
\hline $\mathrm{LSD}_{0.05}$ & & 1.60 & 0.14 & 1.83 & 0.09 & 0.16 & 0.52 & 4.00 \\
\hline
\end{tabular}

The increased Sh/Rt ratio, on F.W. and D.W. basis, with increasing salinity (Table 4) points out that the growth of root was decreased by salinity more than shoot. The higher value of Sh/Rt ratio on D.W. basis than on F.W. basis is due to the higher moisture content in root than in shoot at each salinity level. It can be attributed, the higher sensitivity of root to salinity than shoot, to the higher dehydration (water stress) of root than shoot.

Table 4 showed also significant decrease of shoot height with increasing salinity and at and $100 \mathrm{mM} \mathrm{NaCl}$ treatment, the relative reduction of shoot height was $35.3 \%$.

Photosynthetic pigments : Table 5 showed marked decrease in Chl a, Chl $\mathrm{b}$ and carotenoids contents in leaves of pea plant with increasing salinity.

Proline : Table 5 showed significant increase in the concentration of proline at $100 \mathrm{mM} \mathrm{NaCl}$ treatment with a relative increase of $326.2 \%$. However, there were no significant variations in proline contents at 0,25 , and $50 \mathrm{mM} \mathrm{NaCl}$ treatments. It has been reported that high significant proline concentration in plant leaves is, generally, the consequence of salinity (Olmos and Hellin, 1996; Fedina and Tsonev, 1997; Wang et al., 2007 and Ahmadi et al., 2009).

Salinity-gibberellic acid interaction : Table 4 showed significant increase of shoot F.W. and D.W. with foliar application by $\mathrm{GA}_{3}$. At the control plant $(00$ $\mathrm{mM} \mathrm{NaCl}$ ) the relative increases, with 50 and $100 \mathrm{mg} \mathrm{GA}_{3} \mathrm{I}^{-1}$, were 19.9 and $28.1 \%$ for shoot F.W. and were 8.7 and $20.7 \%$ for shoot, D.W. respectively. At $25 \mathrm{mM} \mathrm{NaCl}$ treatment., these values were 22.0 and $39.3 \%$ for shoot F.W. and were 21.3 and $37.7 \%$ for shoot D.W., respectively. At $50 \mathrm{mM} \mathrm{NaCl}$, these values were 49.9 and $18.1 \%$ for shoot F.W. and were 64.3 and $16.3 \%$ for shoot D.W., respectively. At $100 \mathrm{mM} \mathrm{NaCl}$, these values were 18.2 and $19.6 \%$ for shoot F.W. and were- $20.8 \%$ and $-29.2 \%$ for shoot D.W., respectively. On the other hand, there were no significant stimulating effects on the root F.W. and D.W. at all levels of salinity as a result of foliar application with $\mathrm{GA}_{3}$ (Table 4). These data indicate that root growth had no ability to response to $\mathrm{GA}_{3}$ foliar application at all levels of $\mathrm{NaCl}$ salinity. 
Table 5 :The mean value of photosynthetic pigments (mg $100 \mathrm{~g}^{-1} \mathrm{~F} . \mathrm{W}$ ) and proline ( $\mu \mathrm{M} \mathrm{g}^{-1}$ F.W) in leaves of pea plant after 38 days from sowing as influenced by the interaction between $\mathrm{NaCl}$ and gibberillic acid uncentrations.

\begin{tabular}{|c|c|c|c|c|c|}
\hline \multicolumn{2}{|l|}{ Treatments } & \multirow[b]{2}{*}{ Chl a } & \multirow[b]{2}{*}{ Chl b } & \multirow[b]{2}{*}{ Carotenoids } & \multirow[b]{2}{*}{ Proline } \\
\hline $\begin{array}{l}\mathrm{NaCl}(\mathrm{m} \mathrm{M}) \\
(\mathrm{mM})\end{array}$ & \begin{tabular}{|l|} 
Gib. \\
$\left(\mathrm{Mg} \mathrm{I}^{-1}\right)$
\end{tabular} & & & & \\
\hline 0 & $\begin{array}{l}0 \\
50 \\
100\end{array}$ & $\begin{array}{c}73.52 \mathrm{ac} \\
77.63 \mathrm{ab} \\
81.08 \mathrm{a}\end{array}$ & $\begin{array}{c}37.98 \mathrm{ad} \\
43.02 \mathrm{a} \\
42.77 \mathrm{a}\end{array}$ & $\begin{array}{c}30.78 \mathrm{ac} \\
34.90 \mathrm{a} \\
35.79 \mathrm{a}\end{array}$ & $\begin{array}{l}1.26 \mathrm{~b} \\
0.66 \mathrm{~b} \\
0.64 \mathrm{~b}\end{array}$ \\
\hline 25 & \begin{tabular}{|l}
0 \\
50 \\
100 \\
\end{tabular} & $\begin{array}{l}69.83 \mathrm{ac} \\
69.41 \mathrm{ac} \\
63.70 \mathrm{bd}\end{array}$ & $\begin{array}{l}37.78 \mathrm{ad} \\
38.54 \mathrm{ac} \\
32.31 \mathrm{~cd}\end{array}$ & $\begin{array}{l}28.06 \mathrm{bc} \\
31.67 \mathrm{ac} \\
31.55 \mathrm{ac}\end{array}$ & $\begin{array}{l}0.86 b \\
0.67 b \\
0.65 b\end{array}$ \\
\hline 50 & $\begin{array}{l}0 \\
50 \\
100\end{array}$ & $\begin{array}{c}62.15 \mathrm{bd} \\
53.22 \mathrm{~d} \\
52.86 \mathrm{~d}\end{array}$ & $\begin{array}{c}32.77 \mathrm{~cd} \\
30.03 \mathrm{~cd} \\
29.64 \mathrm{~d}\end{array}$ & $\begin{array}{c}25.77 \mathrm{c} \\
26.77 \mathrm{bc} \\
27.66 \mathrm{bc}\end{array}$ & $\begin{array}{l}0.75 b \\
0.77 b \\
0.86 b\end{array}$ \\
\hline 100 & $\begin{array}{l}0 \\
50 \\
100 \\
\end{array}$ & $\begin{array}{l}60.47 \mathrm{~cd} \\
63.30 \mathrm{bd} \\
66.99 \mathrm{ad}\end{array}$ & $\begin{array}{l}33.29 \mathrm{bd} \\
35.58 \mathrm{ad} \\
41.37 \mathrm{ab}\end{array}$ & $\begin{array}{l}28.71 \mathrm{bc} \\
31.41 \mathrm{ac} \\
32.75 \mathrm{ab}\end{array}$ & $\begin{array}{l}5.37 \mathrm{a} \\
5.54 \mathrm{a} \\
4.56 \mathrm{a} \\
\end{array}$ \\
\hline LSD $_{0.05}$ & & 14.42 & 7.62 & 5.53 & 1.62 \\
\hline
\end{tabular}

Table 4 showed increasing Sh/Rt ratio on both F.W. and D.W. basis with increasing salinity, and within each salinity treatment with increasing dose of $\mathrm{GA}_{3}$ foliar application. This indicates the effectiveness of $\mathrm{GA}_{3}$ foliar application for stimulating shoot growth as compared with root growth.

Foliar application of $\mathrm{GA}_{3}$ significantly increased shoot height relative to the $\mathrm{GA}_{3}$ - untreated plant. At $00 \mathrm{mM} \mathrm{NaCl}$, the relative increases, with 50 and $100 \mathrm{mg} \mathrm{GA}{ }_{3}{ }^{-1}$ foliar application, were 91.5 and $101.3 \%$, respectively. At 25 $\mathrm{mM} \mathrm{NaCl}$, there values were 95.0 and $96.9 \%$; at $50 \mathrm{mM} \mathrm{NaCl}$, these values were 98.4 and $75.6 \%$; and at $100 \mathrm{mM} \mathrm{NaCl}$, these values were 66.4 and $67.4 \%$, respectively. These date indicate the effective role of the stimulating action of $\mathrm{GA}_{3}$ for improving shoot height whether under normal non-saline condition or under salinity stress. It is also clear that foliar application by 50 $\mathrm{mg} \mathrm{GA}_{3} \mathrm{I}^{-1}$ has very close similar effect as by foliar application with $100 \mathrm{mg}$ $\mathrm{GA}_{3} \mathrm{I}^{-1}$.

Foliar application of $\mathrm{GA}_{3}$ of the control plant $(00 \mathrm{mM} \mathrm{NaCl})$ markedly increased $\mathrm{Chl} \mathrm{a}, \mathrm{Chl} \mathrm{b}$ and carotenoids. However, this effect was not pronounced at 25, 50 and $100 \mathrm{mM} \mathrm{NaCl}$ treatments (Table 5). This indicates the in-effectiveness of $\mathrm{GA}_{3}$ under salinity stress on photosynthetic pigments contents in plant leaves.

It is clear from Table 5 that there were no significant effects on the concentration of proline in leaves of pea plant as a result of foliar application by 50 and $\left.100 \mathrm{mg} \mathrm{GA}_{3}\right|^{-1}$, at each level of $\mathrm{NaCl}$ treatment.

Pea plant at 88 days from sowing

Growth characters : Table 6 showed significant decrease in shoot and root F.W. at $50 \mathrm{mM} \mathrm{NaCl}$ treatment in addition total inhibition of plant growth at $100 \mathrm{mM} \mathrm{NaCl}$ treatment. The relative reduction of shoot F.W. at $50 \mathrm{mM} \mathrm{NaCl}$ was $41.8 \%$ and that of root F.W. was $41.4 \%$. This indicates that both shoot and root growth had similarly and significantly decreased at $50 \mathrm{mM} \mathrm{NaCl}$ 
treatment. There was also significantly decrease in pods F.W. at $50 \mathrm{mM} \mathrm{NaCl}$ with relative decrease of $46.0 \%$.

Table 6 :The mean value of pea plant growth characters (g. plant ${ }^{-1}$ ) and total sugars ( $\mathrm{M} \mathrm{g.g^{-1 }}$ D.W) of plant after 88 days from sowing as influenced by the interaction between $\mathrm{NaCl}$ and gibberillic acid concentrations.

\begin{tabular}{|c|c|c|c|c|c|c|c|}
\hline \begin{tabular}{|l} 
Treatments \\
$\mathrm{NaCl}(\mathrm{m} \mathrm{M})$
\end{tabular} & Gib.(mg l' $\left.{ }^{-1}\right)$ & Shoot F.W & Root F.W & Pods F.W & Grains F.W & Grains D.W & $\begin{array}{c}\text { Total } \\
\text { sugars }\end{array}$ \\
\hline 0 & $\begin{array}{l}0 \\
50 \\
100\end{array}$ & $\begin{array}{c}46.37 \mathrm{a} \\
37.03 \mathrm{ab} \\
43.14 \mathrm{a}\end{array}$ & $\begin{array}{c}31.58 \mathrm{a} \\
22.73 \mathrm{ac} \\
21.28 \mathrm{bc}\end{array}$ & \begin{tabular}{|c|}
$43.07 \mathrm{a}$ \\
$30.16 \mathrm{bc}$ \\
$30.74 \mathrm{ac}$
\end{tabular} & $\begin{array}{c}19.36 \mathrm{a} \\
9.88 \mathrm{bc} \\
10.08 \mathrm{bc}\end{array}$ & $\begin{array}{l}4.10 \mathrm{a} \\
2.08 \mathrm{bc} \\
2.30 \mathrm{bc}\end{array}$ & $\begin{array}{r}92.92 \mathrm{a} \\
125.30 \mathrm{a} \\
112.21 \mathrm{a}\end{array}$ \\
\hline 25 & $\begin{array}{l}0 \\
50 \\
100\end{array}$ & $\begin{array}{c}46.20 \mathrm{a} \\
39.77 \mathrm{ab} \\
35.19 \mathrm{ac}\end{array}$ & $\begin{array}{l}26.58 a b \\
23.37 a c \\
21.65 b c\end{array}$ & $\begin{array}{l}41.49 a b \\
33.78 \mathrm{ac} \\
30.19 \mathrm{bc}\end{array}$ & $\begin{array}{c}12.94 \mathrm{~b} \\
10.72 \mathrm{bc} \\
8.04 \mathrm{~cd}\end{array}$ & $\begin{array}{l}2.54 \mathrm{~b} \\
2.13 \mathrm{bc} \\
1.75 \mathrm{bd}\end{array}$ & $\begin{array}{c}107.67 \mathrm{a} \\
88.17 \mathrm{a} \\
110.17 \mathrm{a}\end{array}$ \\
\hline 50 & \begin{tabular}{|l}
0 \\
50 \\
100
\end{tabular} & $\begin{array}{c}26.98 b c \\
28.59 b c \\
20.90 \mathrm{c}\end{array}$ & $\begin{array}{l}18.51 \mathrm{bd} \\
15.21 \mathrm{~cd} \\
9.53 \mathrm{~d}\end{array}$ & $\begin{array}{c}23.26 \mathrm{~cd} \\
13.56 \mathrm{~d} \\
13.00 \mathrm{~d}\end{array}$ & $\begin{array}{l}7.21 \mathrm{~cd} \\
3.91 \mathrm{~d} \\
3.47 \mathrm{~d}\end{array}$ & $\begin{array}{l}1.48 \mathrm{~cd} \\
0.87 \mathrm{~d} \\
0.74 \mathrm{~d}\end{array}$ & $\begin{array}{l}141.84 \mathrm{a} \\
106.92 \mathrm{a} \\
124.63 \mathrm{a}\end{array}$ \\
\hline 100 & $\begin{array}{l}0 \\
50 \\
100\end{array}$ & $\begin{array}{l}- \\
-\end{array}$ & $\begin{array}{l}- \\
- \\
-\end{array}$ & $\begin{array}{l}- \\
- \\
-\end{array}$ & $\begin{array}{l}- \\
- \\
-\end{array}$ & $\begin{array}{l}- \\
- \\
-\end{array}$ & $\begin{array}{l}- \\
- \\
-\end{array}$ \\
\hline $\operatorname{LSD}_{0.05}$ & & 14.46 & 9.20 & 12.42 & 4.79 & 1.04 & 74.60 \\
\hline
\end{tabular}

There were also significant reductions in the grains F.W. at 25 and 50 $\mathrm{mM} \mathrm{NaCl}$ which represented relative decreases of 33.2 and $62.8 \%$, respectively. Similar significant reductions in the grains D.W. were found at 25 and $50 \mathrm{mM} \mathrm{NaCl}$ and represented values of relative reduction of 38.1 and $63.9 \%$, respectively. It is also clear from Table 6 that the moisture contents in the grains decreased with increasing salinity and were 12.26, 10.40 and 5.73 g. plant $^{-1}$ at 0,25 and $50 \mathrm{mM} \mathrm{NaCl}$, respectively. This indicates that the dehydration of pea grain is increased when plant is grown under salinity stress.

Total sugars : Table 6 showed no significant variations in the amounts of total sugars in the grains with increasing salinity. However, marked increase in total sugar can be observed at $50 \mathrm{mM} \mathrm{NaCl}$ treatment. It is reported that accumulation of soluble carbohydrates in plant occurs as a response to salinity (Ashraf and Harris, 2004).

Salinity-gibberellic acid interaction : Foliar application of $\mathrm{GA}_{3}$, at levels of 50 and $100 \mathrm{mgl}^{-1}$, had no significant effect on the shoot and root F.W. at all salinity treatments. However, at $00 \mathrm{mM} \mathrm{NaCl}$ (the control plant), foliar application by $\left.100 \mathrm{mM} \mathrm{GA}_{3}\right|^{-1}$ decreased significantly root F.W. Also, foliar application by 50 and $\left.100 \mathrm{mg} \mathrm{GA}\right|^{-1}$ decreased significantly pods F.W. at 00 $\mathrm{mM} \mathrm{NaCl}$ (the control plant).

Table 6 showed that foliar application of $\mathrm{GA}_{3}$ at levels of 50 and 100 $\mathrm{mgl}^{-1}$ and at the control plant $(00 \mathrm{mM} \mathrm{NaCl})$ significantly decreased grains F.W. This is also found at $25 \mathrm{mM} \mathrm{NaCl}$ with $\left.100 \mathrm{mg} \mathrm{GA}_{3}\right|^{-1}$. Also, there were significant decreases of grains D.W. at $00 \mathrm{mM} \mathrm{NaCl}$ (the control plant) with 50 and $\left.100 \mathrm{mg} \mathrm{GA}_{3}\right|^{-1}$ and at $25 \mathrm{mM} \mathrm{NaCl}$ treatment with $\left.100 \mathrm{mg} \mathrm{GA}_{3}\right|^{-1}$. At the control plant ( $00 \mathrm{mM} \mathrm{NaCl}$ ), the relative decreases of grains F.W. and D.W, with $50 \mathrm{mg} \mathrm{GA}_{3}{ }^{-1}$ foliar application, were 49.0 and $49.3 \%$, respectively, 
and with $\left.100 \mathrm{mg} \mathrm{GA}_{3}\right|^{-1}$ foliar application, were 47.9 and $43.9 \%$, respectively. These data indicate that foliar application of $\mathrm{GA}_{3}$ did not significantly stimulate the growth of 88 days old plant. However, another study reported that $\mathrm{GA}_{3}$ foliar application usually overcomes the effect of salt stress and improve the growth parameters; yield and yield components of salt-stressed plant (Akbari et al., 2008).

Relative growth rate (RGR) : The relative growth rates at 0,25 and $50 \mathrm{mM}$ $\mathrm{NaCl}$ treatments (without $\mathrm{GA}_{3}$ treatments) for shoot F.W. were $0.79,0.79$ and $0.43 \mathrm{~g} . \mathrm{g}^{-1}$ day, and for root F.W. were $0.42,0.32$ and $0.23 \mathrm{~g} \cdot \mathrm{g}^{-1}$ day, respectively. This clearly shows that root growth was more inhibited by salinity than shoot at each salinity level. The data also showed that $50 \mathrm{mM}$ $\mathrm{NaCl}$ treatment decreased markedly the RGR of shoot and root as compared with those of $00 \mathrm{mM}$ and $25 \mathrm{mM} \mathrm{NaCl}$.

The values of the RGR at 0,25 and $50 \mathrm{mM} \mathrm{NaCl}$ with foliar application by $\left.50 \mathrm{mg} \mathrm{GA}{ }_{3}\right|^{-1}$ were $0.57,0.62$ and $0.41 \mathrm{~g}^{-1} \mathrm{~g}^{-1}$ day for shoot F.W. and were $0.26,0.28$ and $0.16 \mathrm{~g} . \mathrm{g}^{-1}$ day for root F.W., respectively. These values, with $100 \mathrm{mg} \mathrm{GA}{ }_{3}{ }^{-1}$, were $0.68,0.51$ and $0.29 \mathrm{~g}^{-\mathrm{g}^{-1}}$ day for shoot F.W. were 0.24 , 0.25 and $0.08 \mathrm{~g} . \mathrm{g}^{-1}$ day for root D.W. These data indicate low response of root growth to $\mathrm{GA}_{3}$ foliar application and relatively high response of shoot growth to $\mathrm{GA}_{3}$ foliar application.

\section{CONCLUSION}

The obtained results showed that increasing $\mathrm{NaCl}$ concentration in water of irrigation more than $25 \mathrm{mM}$ (abut more than $4 \mathrm{dSm}^{-1}$ ) after germination decreased significantly the growth and yield of pea plant grown on sand culture. Increasing the concentration of $\mathrm{NaCl}$ to $100 \mathrm{mM}$ decreased the growth of 38 days old plant and inhibited totally the growth of 88 days old plant.

Foliar application of kinetin at 25 and $50 \mathrm{mgl}^{-1}$ had no significant effects to overcome salt stress on plant growth. On the other hand, foliar application by $\mathrm{GA}_{3}$ at 50 and $100 \mathrm{mgl}^{-1}$ improved growth characters of 38 days old plant and did not affect the growth and yield of 88 days old plant.

\section{REFERENCES}

Ahmadi, A., Y.Emam and M. Pessaraki (2009) Response of various cultivars of wheat and maize to salinity stress. J. Food Agric. Environ. 7:123-128

Akbari, N., M.Barani and H.Ahmadi (2008) Effect of gibberellie acid $\left(\mathrm{GA}_{3}\right)$ on agronomic traits of green gram (Vigna rediata L. Wilezek) irrigated with different levels of saline water. World Applied Sci. J. 5: 199-203

Ashraf, M. and P.J.C. Harris (2004) Potential biochemical indicators of salinity tolerance in plants. Plant Sci. 166: 3-16

Bates, L.S., R.P.Waldern and I.D. Teare (1973) Rapid determination of free proline for water - stress studies. Plant and Soil 39: 205-205. 
Dubois, M.; K.A. Gilles; J.K.Hamilton; P.A. Roers, and F. Smith (1956) Coloremetric method for determination of sugar and related substances. Anal. Chem. 28: 350-356.

Fedina, I.S. and T.D. Tsonev (1997) Effect of pretreatment with methyl jasmonate on the response of Pisum sativum to salt stress.J. Plant Physiol. 151: 735-740

Gadallah, M.A.A.(1999) Effect of kinetin on growth, grain yield and some mineral elements in wheat plants grown under excess salinity and oxygen deficiency. Plant Growth Regul. 27 : 63-74

Hewitt, E.G.(1966)Sand and Water Culture Methods Used in The Study of Plant Nutrition. Technical Communication No. 22. $2^{\text {nd }}$ Ed. Commonwealth Agricultural Bureaux, Fornham Royal, England.

Kumar, S.G.,A.M.Reddy and C.Sudhakar (2003). $\mathrm{NaCl}$ effects on proline metabolism in two high yieldirg genotypes of mulberry (Morus alba L.) with contrasting salt tolerance. Plant Sci. 165:1245-1251.

Lutt, S., V.Majerus and J.M. Kinct (1999). NaCl effects on proline metabolism in rice (Oryza sativa $L$ )seedlings. Physiol. Plant : 105:450-458

Moran, R. and D. Porath (1980) Chlorophyll determination in intact tissues using N,N-dimethylformamide. Plant Physiol.65: 478-479.

Munns, R. and J.B.Passioura (1984) Effect of prolonged exposure to $\mathrm{NaCl}$ on the osmotic pressure of leaf xylem sap from intact, transpiring barely plants. Aust. J. Plant Physiol. 11: 497-507.

Munns, R.(2002)Comparative physiology of salt and water stress. Plant, Cell and Environ. 25: 239-250

Munns, R., R.A. James, and A. Lauchli (2006) Approches to increasing the salt tolerance of wheat and other cereals. J.Exp.Bot. 57: 1025-1043

Olmos, E. and E.Hellin (1996) Mechanism of salt to lerance in a cell line of Pisum sativum : biochemical and physiological aspects. Plant Sci. 120: $34-45$

SAS Inst. (1985): SAS User's Guide, Statistics, Version 5 Ed. SAS Inst. Inc., Cary, Nc.

Tester, M. and R.Davenport (2003) $\mathrm{Na}^{+}$tolerance and $\mathrm{Na}^{+}$transport in higher plants. Annals of Botany 91: 503-527.

Wang, Z-Q., Y-Ze Yuan, J-Q.Ou, Q-H. Lin, and C-F. Zhang (2007) Glutamine synthetase and glutamate dehydrogenase contribute differentially to proline accumulation in leaves of wheat (Triticum aestivum L.) seedlings exposed to different salinity. J. Plant Physiol. 164: 695-701. 
استجابة نبات البسلة النامى فى مزرعـة رمليـة تحت إجهاد ملحى للإضـافة الورقية

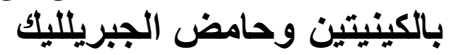

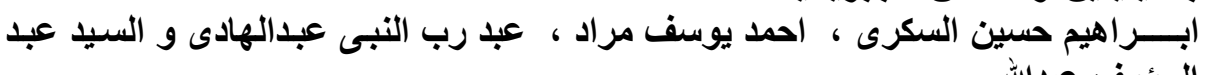
الرؤوف عبدالله قسم الأراضى والمياه ـ كلية الزراعة - جامعة الإسكندرية ـ مصر

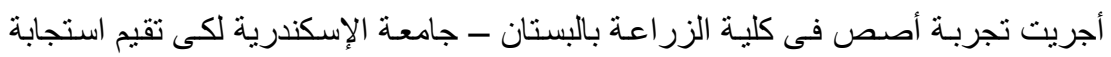

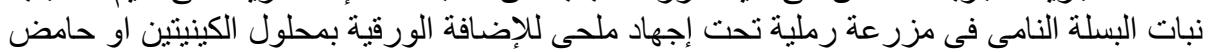

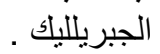

زرعت البذور فى اصص تحتوى 10 كيلو جرامات رمل سبق غسله بالماء واستخدم فى ،

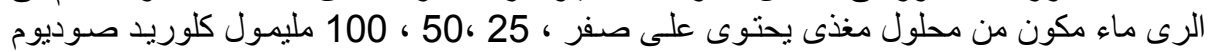

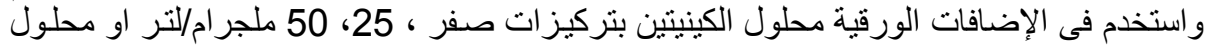

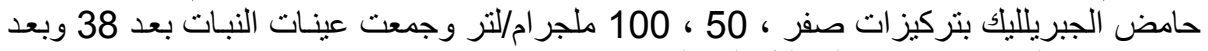

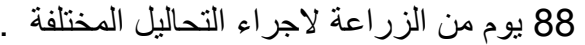

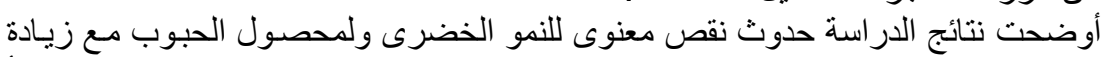

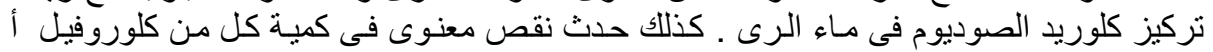

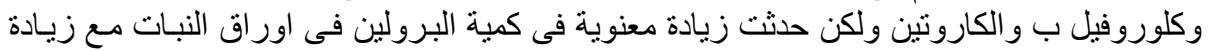

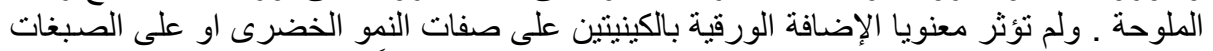

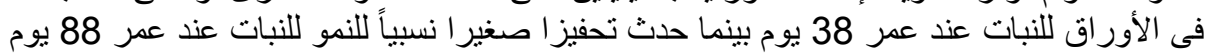

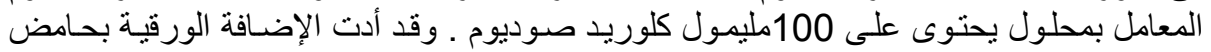

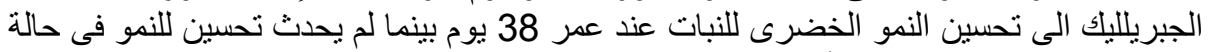

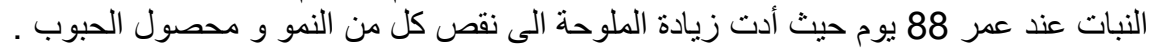

كلية الزراعة - جامعة المنصورة

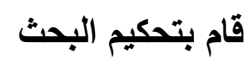

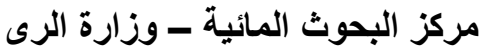

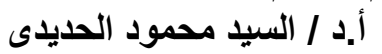

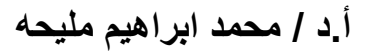

